\title{
Comparison of Eurofit Test Results of 11-17-Year-Old Male and Female Students in Kosovo
}

\author{
Milaim Berisha \\ Institute of Educational Sciences, \\ Faculty of Sports Science, Sakarya University, Turkey \\ Murat Cilli \\ Department of Coaching Education, \\ Faculty of Sports Science, Sakarya University, Turkey
}

Doi: 10.19044/esj.2017.v13n31p138 URL:http://dx.doi.org/10.19044/esj.2017.v13n31p138

\begin{abstract}
This study aims to compare EuroFit test results of 11-17-year-old males and females in Kosovo. 742 students were included in the study. 347 females and 395 males were determined by random selection from the schools in urban and rural areas of all regions. Kosovo's general population rate $(52 \%$ male $48 \%$ female) was considered when determining the proportion of male and female students. Anthropometric characteristics including height, weight, and Body Mass Index (BMI) of students and the motoric characteristics including the values obtained from the tests such as flamingo balance, plate tapping, sit and reach, standing broad jump, handgrip strength, sit-ups $(30 \mathrm{sec}$ ), bent arm hang, 10x5m shuttle run and $20 \mathrm{~m}$ endurance were compared. As a result, there was no statistically significant difference between the anthropometric characteristics of male and female students in adolescence; however, it was observed that as the age increased, males became heavier and taller than females $(p<0.05)$. In general, while there was no statistically significant difference between males and females in flamingo balance, plate tapping and sit and reach tests ( $p>0.05)$, males were determined to be more successful than females in standing broad jump test, handgrip strength test, sit-ups $(30 \mathrm{sec})$ and $20 \mathrm{~m}$ endurance tests $(\mathrm{p}<0.05)$.

It is observed that students in Kosovo are more successful than the other countries regarding motoric tests such as the anthropometric characteristics, which are thought to be more related to genetics, and speed/agility of arms and legs. On the other hand, they are unsuccessful in comparison with other countries with regard to flexibility and endurance in tests which are thought to be influenced by factors such as lifestyle, nutrition, and training.
\end{abstract}

Keywords: EuroFit, Gender, Kosovo, Physical fitness 


\section{Introduction}

Even though Kosovo is one of the youngest countries in the European region, the number of studies carried out within the country regarding the development and physical fitness of children is very limited. From this point of view, further studies will provide significant benefits. These studies aim to follow the healthy development of children in Kosovo, to guide them to appropriate sports branches, to improve the quality of sports and to evaluate the physical and motor skills of young people according to other countries.

Many researchers have emphasized that measuring basic motor skills such as height, weight, Body Mass Index (BMI), standing broad jump, balance, and endurance are important in having information about physical structure and health status. In line with this objective, EuroFit test protocol is frequently preferred to measure the physical fitness of children especially in school age. According to Asmussen et al. (1983), the Eurofit Test Battery (EUROFIT) is used by many developed countries to indicate children's health status, guide children to sports branches, and compare physical and motoric characteristics between countries (Asmussen, Klissouras, Tuxworth, Lofi, \& Leger, 1983). Eurofit Test Battery includes the following tests; Height (L), Weight (W), Body Mass Index (BMI), Flamingo Balance Test (FLB), Plate Tapping Test (PLT), Sit-and-Reach Test (SAR), Standing Broad Jump Test (SBJ), Handgrip Strength Test (Right) (HGRR), Handgrip Strength Test (Left) (HGRL), Sit-ups (30sec) (SUP), Bent Arm Hang Test (BAH), 10 x 5 Meter Shuttle Run Test (SHR), 20 m Endurance Test (ESR). (Asmussen et al., 1983; Council of Europe, 1987). In European countries, the Eurofit Test Battery (EUROFIT) has been applied to school children between the ages of 6 and 18 with the establishment of the Physics and Sports Council in (1956). (Asmussen et al., 1983; Council of Europe, 1987; Kemper \& Mechelen, 1996). It is observed that scientific studies related with the evaluation of physical and basic motor skills and the determination of norm values for different age groups and gender are carried out in many different countries such as Latvia, Volbekiene and Griciltte (2007) (Volbekiene \& Griciltte, 2007), Canada, Adhikari and McNeely (2015) (Adhikari \& McNeely, 2015); Norway, Fjørtoft, Pedersen, Sigmundsson and Verbeke (2011), (Fjørtoft, Pedersen, Sigmundsson, \& Vereijken, 2011) and in Turkey, Bayraktar (2010). Considering this information, it is aimed to evaluate basic anthropometric and motoric skills of children living in Kosovo through EuroFit tests.

The purpose of this study is to determine the basic anthropometric and motor characteristics of 11-17-year-old males and females living in Kosovo, to examine the differences according to age and sex, and to compare the results with the values of other countries. 


\section{Method}

Approximately 300 thousand students are educated (11-17 age group) in Kosovo which is composed of 26 cities in 7 geographical regions (Agjencia e Statistikave të Kosovës, 2014). 742 students were included in the study, 347 females and 395 males, determined by random selection from the schools of urban and rural areas in all regions. Kosovo's general population rate $(52 \%$ male $48 \%$ female) was considered when determining the proportion of male and female students (Agjencia e Statistikave të Kosovës, 2014). Volunteering students, who did not have any acute or chronic illnesses that impede the conduct of the tests, participated in the study with the permission of the Ministry of Education and with the support of school principals and parents.

The tests in Table 1 were applied to determine the basic anthropometric characteristics of students and the basic motoric characteristics of the Eurofit test battery. The tests were carried out between 15.04.2017-20.05.2017 through using measurement equipment provided by the physical education teachers in the schools.

Table 1. Eurofit Test Protocol (Council of Europe, 1987)

\begin{tabular}{|c|c|c|}
\hline Eurofit Test & Dimension & Factor \\
\hline Height (L) & \multirow{3}{*}{ Anthropometric measures } & \multirow{3}{*}{$\begin{array}{l}\text { Anthropometric } \\
\text { characteristics }\end{array}$} \\
\hline Weight (KG) & & \\
\hline Body mass index (BMI) & & \\
\hline Endurance shuttle run (ESR) & $\begin{array}{l}\text { Cardio-respiratory } \\
\text { endurance }\end{array}$ & $\begin{array}{c}\text { Cardio-respiratory } \\
\text { endurance }\end{array}$ \\
\hline Hand grip (HGR) & \multirow{2}{*}{ Strength } & Static strength \\
\hline Standing broad jump (SBJ) & & Explosive strength \\
\hline Bent arm hang (BAH) & \multirow{2}{*}{ Muscular endurance } & Functional strength \\
\hline Sit-ups (SUP) & & Trunk strength \\
\hline $\begin{array}{c}\text { Shuttle run: } 10 \times 5 \text { meters } \\
\text { (SHR) }\end{array}$ & \multirow{2}{*}{ Speed } & Running speed - agility \\
\hline Plate tapping (PLT) & & Speed of limb movement \\
\hline Sit and reach (SAR) & Flexibility & Flexibility \\
\hline Flamingo balance (FLB) & Balance & Total body balance \\
\hline
\end{tabular}

Height (L): This is the vertical distance between the ground and the top of the head when individual is standing in a head-straight position, eyes looking to the front. Heights were measured as bare feet. The head was in Frankfurt Position (the lower part of the eye ad the upper part of the ear was in horizontal position), the body was tense and touched the background wall. A portable measurement device, which was capable of measuring between 80 $\mathrm{cm}$ and $200 \mathrm{~cm}$, which had a stand for feet, which had a sensitivity of $1 \mathrm{~mm}$, was used. 
Weight (KG): The subjects stood straight and bare feet with light clothes on the scale, and held the scale with both hands. The "Tanita BC 545 N Innerscan Segmental Personal Body Analysis" scale was used that was capable of measuring the weight, body fat percentage (5-99 age range), body fat health range indicator (5-99 age range), total body water percentage, muscle mass, body level, bone mineral mass, basal metabolism speed, metabolik age, body mass index, visceral fat, visceral far health range indicator, 5 segmental fat, and 5 segmental muscle properties.

Body Mass Index (BMI): BMI is a criterion of body composition, and calculates the body composition of an individual by taking the weight, and divides it by the square of the height. Weight $(\mathrm{kg}) /[$ Height $(\mathrm{m})] 2$. The "Tanita BC 545 N Innerscan Segmental Personal Body Analysis" scale, which was capable of calculating the weight, body fat percentage (5-99 age range), body fat health range (5-99 age range), total body water percentage, muscle mass, body level, bone mineral mass, basal metabolism speed, metabolic age, body mass index, visceral fat, visceral fat health range indicator, 5 segmental fat, and 5 segmental muscle properties.

Flamingo Balance (FLB): It is used to calculate the general body balance. A 50-cm long, $4 \mathrm{~cm}$ high, and $3 \mathrm{~cm}$ wide metal beam was used in this test. During this test, the subject tries to hold his/her posture just like a Flamingo for a long time with feet on the metal beam. For 1 minute, each intervention (not falls) made to keep the balance on the beam is considered as a point.

Plate Tapping (PLT): It is used to calculate the movement speed of an individual. The subject tries to touch 2 disks with the preferred hand in defined order in a fast way. Two 20 -cm plastic disks are placed on a table. The distance between the two disks to each other is $80 \mathrm{~cm}$ (the edges are 60$\mathrm{cm}$ to each other). $10 \times 20 \mathrm{~cm}$ rectangular plate is placed to an equally far area to both disks. The best score is considered as the final point. The point is the time used to touch each disk for 25 times, and is recorded as a tenth part of a second.

Sit and Reach (SAR): This test is used to measure flexibility, and a "sit and stretch flexibility table" is required. The subject sits in front of a $35 \mathrm{~cm}$ long, $45 \mathrm{~cm}$ wide, $32 \mathrm{~cm}$ high, places his/her feet in the inner side of the plate, and tries to push the bar on the plate as further as possible; the value at the furthest point is recorded as the final score.

Standing Board Jump (SBJ): It is used to measure explosive force. Finger tips are placed just behind the line, and the feet are far to each other in a normal manner. The subject jumps to the possible farthest point in a parallel manner to the ground, by holding his/her arms front, knees bent after releasing the arms. Both feet are placed on the ground simultaneously. The test is perfumed twice, and the best score is recorded. 
Hand Grip (HGR): It is used to measure the static force. The dynamometer is held firmly with the right hand in a $30^{\circ}$ body angle between the arm and body. The test is repeated twice. The best value is recorded.

Sit-Ups (SUP): This test is used to measure the body force. The back of the individual is held straight, hands hold the neck, knees are bent for $90^{\circ}$, the heels and feet are placed horizontally to the mat to sit down. Then the subject lies back, the shoulders touch the mat, and the elbows are held in front to touch the knees, and then the subject returns to sitting position again. The subject holds the hands on the neck throughout the test. This movement is repeated in a fast manner for 30 seconds with the command "Ready, ... Go!". The value (the number of the sit-ups) is recorded after 30 seconds.

Bent Arm Hang Test (BAH): It is used to measure the functional force (the endurance of the muscles of the arm and shoulders). The subject stands under a bar adjusted to enable the subject to reach without jumping. The bar is $2.5 \mathrm{~cm}$ in diameter, and there is a round and horizontal scaffold. The subject holds the bar in the front, shoulders are wide, the thumbs are below, and the other fingers are at the top. The subject receives help until the chin reaches a level that is just above the bar. The subject tries to hold this position as long as possible, and tries not to decline the level of the chin below the bar. The test ends when the level of the eyes drop below the level of the bar. The duration for hold is recorded.

Shuttle Run 10x5 meters (SHR): It is used to measure speedcoordination properties. The subject is ready behind the start line. S/he starts running with the "Start" command with both feeds exceeding the two lines, and runs back after passing the other line. This movement is a cycle, and is repeated for 5 times. In the $5^{\text {th }}$ cycle, the subject passes the Finish Line without slowing down. The total time is recorded.

Endurance Shuttle Run (ESR): The Shuttle Run includes running for 20 meters as an indicator of maximal aerobic capacity and endurance. The speed is controlled with regular intervals with the help of a stereo that produces a beep signal with regular intervals. The latest number of the shuttle at the end of the test is recorded.

To measure the height of the students, a portable, adjustable, $(1 \mathrm{~cm})$ height meter was used. Body weight, Body Mass Index and percentage of body fat were determined by using the TANITA Segmental Body Composition BC-545N. A standard hydraulic hand dynamometer (Baseline 12-0240) was used for measuring handgrip strength. A chronometer (QQ Japanese HS45 10 Lap Memory) was used to measure time in bent arm hang test, plate tapping test and the flamingo balance test.

Data Analysis: The SPSS 22 program was used to analyze Eurofit test values of the research group. T-test (significance level p <0.05) analyses 
were used to determine the differences between descriptive statistics, average and standard deviation $(\overline{\mathrm{X}} \pm \mathrm{sd})$ values and gender-based test results.

\section{Results}

The values of basic anthropometric and motoric tests of the students are presented in tables according to age and gender. The values of the students in each age group are compared according to sex.

Table 2. Comparison of Height (H), Weight (W) and Body Mass Index (BMI) characteristics of 11-17-year-old male and female students.

\begin{tabular}{|c|c|c|c|c|c|c|c|c|}
\hline \multirow{2}{*}{ Age } & \multirow{2}{*}{ Gender } & \multirow{2}{*}{$\mathrm{N}$} & \multicolumn{2}{|c|}{ (L) } & \multicolumn{2}{|c|}{$(\mathrm{W})$} & \multicolumn{2}{|c|}{ (BMI) } \\
\hline & & & $\overline{\mathrm{X}} \pm \mathrm{SD}$ & $\mathrm{P}$ & $\overline{\mathrm{X}} \pm \mathrm{SD}$ & $\mathrm{P}$ & $\overline{\mathrm{X}} \pm \mathrm{SD}$ & $\mathrm{P}$ \\
\hline \multirow{2}{*}{11} & Female & 50 & $1,50 \pm, 07$ & \multirow{2}{*}{0.14} & $39,8 \pm 10,7$ & \multirow{2}{*}{0.16} & $17,1 \pm 3,8$ & \multirow{2}{*}{0.67} \\
\hline & Male & 50 & $1,47 \pm, 05$ & & $37,3 \pm 6,2$ & & $16,8 \pm 2,1$ & \\
\hline \multirow{2}{*}{12} & Female & 54 & $1,55 \pm, 08$ & \multirow{2}{*}{0.40} & $44,5 \pm 9,7$ & \multirow{2}{*}{0.37} & $18,2 \pm 5,3$ & \multirow{2}{*}{0.41} \\
\hline & Male & 55 & $1,54 \pm, 07$ & & $42,9 \pm 9,0$ & & $17,7 \pm 2,5$ & \\
\hline \multirow{2}{*}{13} & Female & 46 & $1,60 \pm, 05$ & \multirow{2}{*}{0.93} & $50,0 \pm 7,9$ & \multirow{2}{*}{0.18} & $18,9 \pm 4,2$ & \multirow{2}{*}{0.75} \\
\hline & Male & 57 & $1,60 \pm, 07$ & & $47,9 \pm 8,4$ & & $18,7 \pm 2,8$ & \\
\hline \multirow{2}{*}{14} & Female & 44 & $1,61 \pm, 04$ & \multirow{2}{*}{$0.00 * *$} & $51,4 \pm 8,4$ & \multirow{2}{*}{0.07} & $19,7 \pm 2,7$ & \multirow{2}{*}{0.20} \\
\hline & Male & 44 & $1,69 \pm, 07$ & & $54,5 \pm 9,0$ & & $19,0 \pm 2,1$ & \\
\hline \multirow{2}{*}{15} & Female & 55 & $1,60 \pm, 07$ & \multirow{2}{*}{$0.00 * *$} & $54,4 \pm 7,2$ & \multirow{2}{*}{$0.00 * *$} & $20.1 \pm 4,2$ & \multirow{2}{*}{0.51} \\
\hline & Male & 61 & $1,72 \pm, 07$ & & $58,7 \pm 10,0$ & & $19,8 \pm 2,6$ & \\
\hline \multirow{2}{*}{16} & Female & 50 & $1,65 \pm, 04$ & \multirow{2}{*}{$0.00 * *$} & $58,3 \pm 6,8$ & \multirow{2}{*}{$0.00 * *$} & $21,1 \pm 2,7$ & \multirow{2}{*}{0.99} \\
\hline & Male & 80 & $1,74 \pm, 07$ & & $64,2 \pm 10,8$ & & $21,0 \pm 3,9$ & \\
\hline \multirow{2}{*}{7} & Female & 44 & $1,67 \pm, 07$ & \multirow{2}{*}{$0.00 * *$} & $56,8 \pm 6,5$ & \multirow{2}{*}{$0.00 * *$} & $21,1 \pm 2,2$ & \multirow{2}{*}{$0.00 * *$} \\
\hline & Male & 48 & $1,76 \pm, 07$ & & $66,1 \pm 10,6$ & & $21,4 \pm 2,7$ & \\
\hline
\end{tabular}

Height (L), Weight (W), Body mass index (BMI)

$* * p<0.00, * p<0.05$

Table 3. Comparison of Flamingo Balance Test (FLB), Plate Tapping Test (PLT), Sit-andReach Test (SAR) and Standing Broad Jump Test (SBJ) characteristics of 11-17-year-old male and female students.

\begin{tabular}{|c|c|c|c|c|c|c|c|c|c|c|}
\hline \multirow{2}{*}{ Age } & \multirow{2}{*}{ Gender } & \multirow{2}{*}{$\mathrm{N}$} & \multicolumn{2}{|c|}{ FLB } & \multicolumn{2}{|l|}{ PLT } & \multicolumn{2}{|c|}{ SAR } & \multicolumn{2}{|c|}{ SBJ } \\
\hline & & & $\overline{\mathrm{X}} \pm \mathrm{SD}$ & $\mathrm{P}$ & $\overline{\mathrm{X}} \pm \mathrm{SD}$ & $\mathrm{P}$ & $\overline{\mathrm{X}} \pm \mathrm{SD}$ & $\mathrm{P}$ & $\overline{\mathrm{X}} \pm \mathrm{SD}$ & $\mathrm{P}$ \\
\hline \multirow[b]{2}{*}{11} & Female & 50 & $16,8 \pm 9,2$ & \multirow[b]{2}{*}{$0.00^{* *}$} & $12,80 \pm 2,36$ & & $0,8 \pm 4,3$ & \multirow[b]{2}{*}{0.28} & $1,29 \pm, 21$ & \multirow[b]{2}{*}{0.97} \\
\hline & Male & 50 & $11,8 \pm 8,3$ & & $14,44 \pm 2,00$ & $0.00^{* *}$ & $\begin{array}{c}- \\
0,1 \pm 4,1\end{array}$ & & $1,29 \pm, 24$ & \\
\hline \multirow{2}{*}{12} & Female & 54 & $10,4 \pm 4,6$ & \multirow{2}{*}{0.38} & $11,34 \pm 1,96$ & 0.59 & $\underline{0,9 \pm 5,8}$ & \multirow{2}{*}{0.75} & $1,38 \pm, 19$ & \\
\hline & Male & 55 & $9,5 \pm 5,8$ & & $11,57 \pm 2,57$ & 0.59 & $0,6 \pm 4,9$ & & $1,54 \pm, 24$ & \\
\hline \multirow[b]{2}{*}{13} & Female & 46 & $10,0 \pm 4,3$ & \multirow[b]{2}{*}{0.52} & $11,07 \pm 2,92$ & & $0,3 \pm 6,2$ & \multirow{2}{*}{$0.03^{*}$} & $1,37 \pm, 26$ & \\
\hline & Male & 57 & $9,4 \pm 4,2$ & & $11,25 \pm 2,31$ & 0.72 & $\begin{array}{c}- \\
2,0 \pm 5,1\end{array}$ & & $1,62 \pm, 29$ & 0.00 \\
\hline \multirow[b]{2}{*}{14} & Female & 44 & $8,8 \pm 4,8$ & \multirow[b]{2}{*}{0.64} & $10,27 \pm 2,02$ & & $2,1 \pm 7,7$ & \multirow{2}{*}{$0.01 *$} & $1,54 \pm, 23$ & \\
\hline & Male & 44 & $9,4 \pm 4,6$ & & $10,27 \pm 2,48$ & 0.65 & $\begin{array}{c}- \\
2,2 \pm 8,2\end{array}$ & & $1,81 \pm, 24$ & 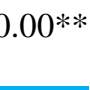 \\
\hline \multirow{2}{*}{15} & Female & 55 & $9.2 \pm 5,9$ & \multirow{2}{*}{0.65} & $10,02 \pm 1,79$ & 015 & $2,0 \pm 8,1$ & \multirow{2}{*}{0.36} & $1,57 \pm, 18$ & \\
\hline & Male & 61 & $9,7 \pm 6,1$ & & $10,02 \pm 2,06$ & 0.15 & $0,5 \pm 8,6$ & & $1,85 \pm, 29$ & \\
\hline
\end{tabular}




\begin{tabular}{|c|c|c|c|c|c|c|c|c|c|}
\hline \multirow{2}{*}{16} & & 50 & & \multirow{2}{*}{0.84} & 96 & \multirow{2}{*}{0.16} & $0,9 \pm 9,6$ & \multirow{2}{*}{0.99} & \\
\hline & & 80 & & & 10,0 & & $\overline{0,9 \pm 8,3}$ & & \\
\hline & & 44 & $9.0 \pm 5,4$ & & $09.87 \pm 1,33$ & & $2,3 \pm 7,3$ & \multirow{2}{*}{0.40} & $1,50 \pm, 29$ \\
\hline & Male & 48 & $7.5 \pm 6,8$ & & $9,87 \pm 1,44$ & & $2,2 \pm 8,0$ & & $1,98 \pm, 50$ \\
\hline
\end{tabular}

Flamingo Balance Test (FLB), Plate Tapping Test (PLT), Sit-and-Reach Test (SAR),

Standing Broad Jump Test (SBJ)

$* * \mathrm{p}<0.00, * \mathrm{p}<0.05$

Table 4. Comparison of Handgrip Strength Test (Right) (HGRR), Handgrip Strength Test (Left) (HGRL), Sit-ups (30sec)(SUP), Bent Arm Hang Test (BAH), 10 x 5 meter Shuttle Run Test (SHR), 20 m endurance test (ESR) characteristics of 11-17-year-old male and female students.

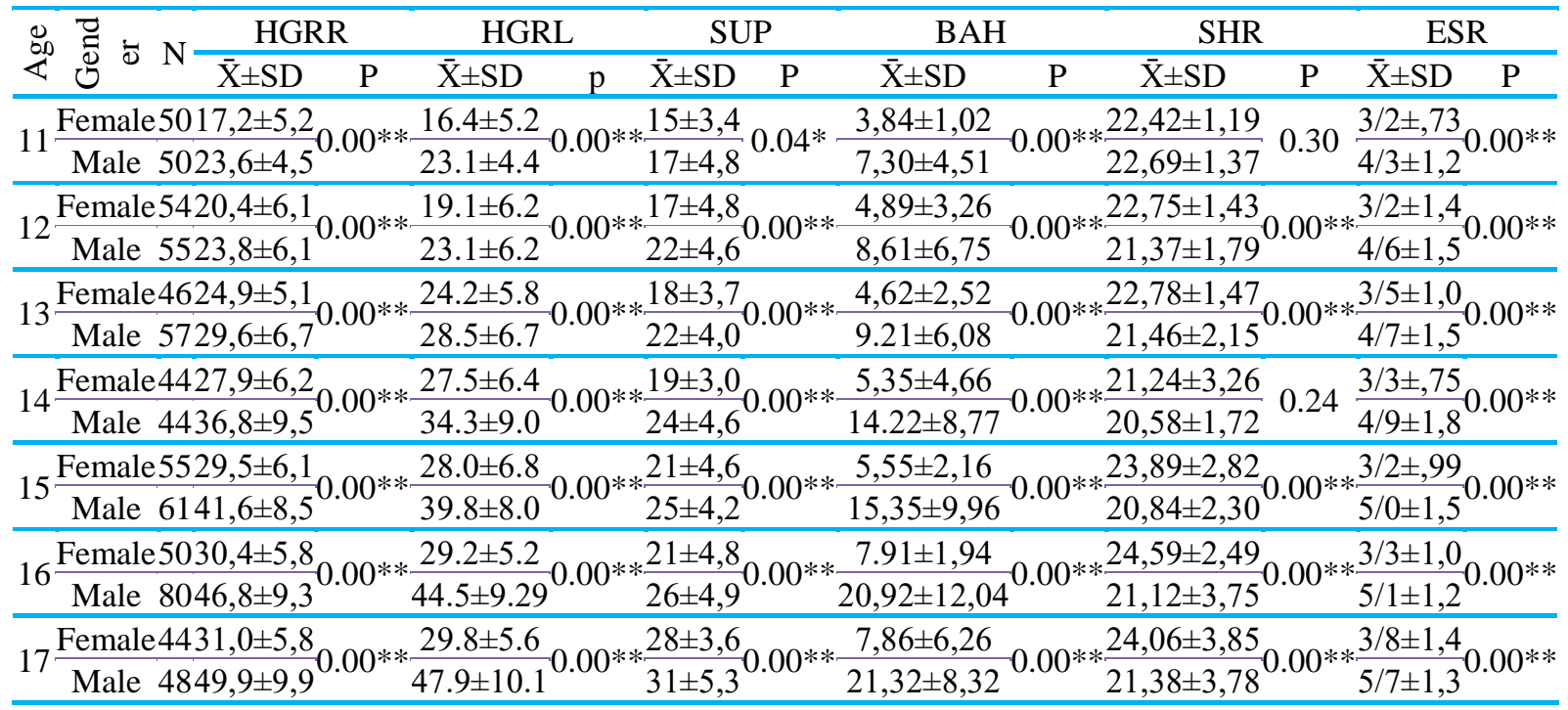

Handgrip Strength Test (Right) (HGRR), Handgrip Strength Test (Left) (HGRL), Sit ups (30sec) (SUP), Bent Arm Hang Test (BAH), 10 x 5 meter Shuttle Run Test (SHR), 20 m endurance Test (ESR).

$* * \mathrm{p}<0.00, * \mathrm{p}<0.05$

\section{Discussion}

In this study, some physical and motoric characteristics of 11-17 years old students living in Kosovo were assessed. The measurement results obtained from the tests carried out in the EuroFit test battery were compared according to age groups in terms of male and female students. Also, the values of male and female students in Kosovo were compared with the values of other countries.

Height $(\boldsymbol{H})$ : In the study, the average height values of female and male students for 11 years of age were $1.50 \pm 0.07$ and $1.47 \pm 0.05$, respectively $(\mathrm{p}>0.14)$. For 12 years of age, female average was $1.55 \pm 0.08$ and male average was $1.54 \pm 0.07(\mathrm{p}>0.04)$. For 13 years of age, female average was $1.60 \pm 0.05$ and male average was $1.60 \pm 0.07$ ( $>0.93$ ). For 14 years of age, 
female average was $1.61 \pm 0.04$ and male average was $1.69 \pm 0.07(\mathrm{p}<0.00)$. For 15 years of age, female average was $1.60 \pm 0.07$ and male average was $1.72 \pm 0.07(\mathrm{p}<0.00)$. For 16 years of age, female average was $1.65 \pm 0.04$ and male average was $1.74 \pm 0.07(\mathrm{p}<0.00)$. Lastly, for 17 years of age, female average was $1.67 \pm 0.07$ and male average was $1.76 \pm 0.07(\mathrm{p}<0.00)$. In the literature, it is seen that females have higher heights in the 11-13-year-old group due to their early adolescence period (Normal Adolescent Development, 2003).

In this study, no significant difference was found between the heights of the male and female students in the 11-13 age group in Kosovo. Also, it was found that males were taller than females after puberty.

When the average height values obtained in the study were compared with the World Health Organization's (WHO) height average values, it was observed that except for 15-year-old female students in Kosovo, the height average of male and female students in all age groups were higher than the world average (Height-for-age Boys 5 to 19 years 2007; Height-for-age Girls 5 to 19 years, 2007). Compared to other countries, it was found that the height values in Kosovo were higher than the height values of the male in 13year-old group in Sweden (Örjan, Kristjan, \& E, 2005). Also, it was found that height values in Kosovo were lower than the height values in Norway, Estonia, and Latvia. Lastly, it was seen that height values of Kosovo were higher than the height values of Africa (Fjørtoft et al., 2011; Jürimäe \& Volbekiene, 1998; Nhantumbo, Saranga, Prista, Basso, \& Maia, 2012).

Weight $(\boldsymbol{W})$ : In the study, the average body weight for 11 years of age were $39.8 \pm 0.10 .7$ for females and $37.3 \pm 6.2$ for males $(\mathrm{p}>0.16)$. For 12 years of age, female average was $44.5 \pm 0.90$ and male average was $42.9 \pm 9.0$ ( $p>0.37)$. For 13 years of age, female average was 50.0 7.9 and male average was $47.9 \pm 8.4(p>0.18)$. For 14 years of age, female average was $51.4 \pm 0.90$ and male average was $54.6 \pm 8.4(\mathrm{p}>0.07)$. For 15 years of age, female average was $54.4 \pm 0.10$ and male average was $58.7 \pm 7.2(\mathrm{p}<0.00)$. For 16 years of age, female average was $58.3 \pm 6.8$ and male average was $64.2 \pm 10.8(\mathrm{p}<0.00)$. Lastly, for 17 years of age, female average was $56.8 \pm 6.5$ and male average was $66.1 \pm 10.6(p<0.00)$. Considering gender, there was no difference between males and females in adolescence. However, after adolescence, it was seen that males were heavier than females. It is stated in the literature that females are lighter than males (Normal Adolescent Development, 2003). Since the rate of growth in adolescence is variable, the body weight can change significantly (Coleman \& Hendry, 1999).

Compared to the countries, it was seen that the students living in Norway, Latvia and Estonia were heavier than the students living in Kosovo (Fjørtoft et al., 2011; Jürimäe \& Volbekiene, 1998). This difference can be attributed to the fact that more than $65 \%$ of the population in Kosovo live in 
the villages (Agjencia e Statistikave të Kosovës, 2014). It was seen that the body weight values in Kosovo were higher than the values in Africa (Nhantumbo et al., 2012). The reason of this can be the poverty level in Africa. However, due to the rapid growth caused by adolescence, the comparison of the body weight of children in this age group can be misleading.

Body Mass Index (BMI): Body Mass Index (BMI) values for 11 years of age were $17.1 \pm 0.38$ for females and $16.8 \pm 0.21$ for males $(\mathrm{p}>0.67)$. For 12 years of age, female value was $18.6 \pm 5.3$ and male value was $17.9 \pm 0.25(\mathrm{p}>0.41)$. For 13 years of age, female value was $18.9 \pm 4.2$ and male value was $18.7 \pm 2.8(\mathrm{p}>0.75)$. For 14 years of age, female value was $19.7 \pm 2.7$ and male value was $19.0 \pm 2.1(\mathrm{p}>0.20)$. For 15 years of age, female value was $20.1 \pm 4.2$ and male value was $19.8 \pm 2.6$ ( $>0.51)$. For 16 years of age, female value was $17.1 \pm 0.38$ and male value was $16.8 \pm 2.1(\mathrm{p}>0.99)$. For 17 years of age, female value was $21.1 \pm 2.2$ and male value was $21.4 \pm 2.4$ $(\mathrm{p}<0.00)$.

According to these findings, there was no difference between the Body Mass Index (BMI) values of males and females in 11-16 age group. However, in the 17-year-old group, the Body Mass Index values of males were higher than females.

Considering other countries, the Body Mass Index (BMI) values of the students in Kosovo were lower than the values of the students in Norway, Colombia, and India (Alexander et al., 2016; Fjørtoft et al., 2011). It was seen that the Body Mass Index (BMI) values of 11 and 16-year-old male and female students living in Kosovo were lower than the values reported by the World Health Organization (WHO) (BMI-for-age Boys 5 to 19 years 2007; BMI-for-age Girls 5 to 19 years, 2007). It was also seen that the Body Mass Index (BMI) values of 13 and 17-year-old male and female students were higher than the values reported by the World Health Organization (WHO). Also, while the Body Mass Index (BMI) values of 12 and 15-year-old female students were lower than the values reported by the World Health Organization (WHO), the Body Mass Index values of male students were higher. Lastly, it was seen that the Body Mass Index (BMI) values of 12 and 15-year-old female students were higher than the Body Mass Index (BMI) values reported by the World Health Organization (WHO), and the Body Mass Index values of male students were lower. (Örjan et al., 2005)

Flamingo Balance Test (FLB): Flamingo Balance Test average number of falls in 1 minute for 11-year-old individuals were found as $16.8 \pm 3.8$ for females and as $11.8 \pm 8.3$ for males $(\mathrm{p}<0.00)$. For 12 years of age, female average was $10.4 \pm 5.4$ and male average was $9.5 \pm 5.8(\mathrm{p}>0.38)$. For 13 years of age, female average was $10.0 \pm 4.2$ and male average was $9.4 \pm 4.2$ $(\mathrm{p}>0.52)$. For 14 years of age, female average was $8.8 \pm 2.7$ and male average 
was $9.4 \pm 4.6$ ( $>0.64)$. For 15 years of age, female average was $9.2 \pm 4.2$ and male average was $9.7 \pm 6.1(\mathrm{p}>0.65)$. For 16 years of age, female average was $9.2 \pm 2.7$ and male average was $9.0 \pm 3.9$ ( $p>0.84$ ). Lastly, for 17 years of age, female average was $9.0 \pm 2.2$ and male average was $7.5 \pm 2.7(\mathrm{p}<0.00)$.

The studies in the literature have similarities with this study. It was seen that the balance protection ability of 11 and 17-year-old male students was higher than female students. In the 12-16 age groups, there was no difference in balance protection ability between males and females. When the anthropometric and motoric characteristics of 12-16 age group were examined, the development of balance ability did not show parallelism with age. However, as a result of the study done by Singh et al. (2015), it was determined that there was a meaningful relationship between balance ability and anthropometric characteristics (Singh et al., 2015).

Compared to the countries, female students in Poland were more successful than female students in Kosovo in terms of their ability to maintain balance. Male students in 12-15 age groups in Kosovo were more unsuccessful in balance maintenance ability than the male students in Poland. 11-year-old male students in Kosovo were more successful than the male students in Poland (Wilczewski, Sklad, Krawczyk, Saczuk, \& Majle, 1996). 12-17-year-old boys and girls in Kosovo were more successful than the ones in Latvia. The same results were achieved for male students aged 11. For females aged 11, the values in Latvia were higher than those in Kosovo. In the Flamingo balance test, 11-year-old boys and girls in Estonia were more successful than the boys and girls in Kosovo.

Both males and females in 12-14 age groups in Kosovo were more successful than the ones in Estonia. In the 13, 15, 16 and 17 age groups, males in Kosovo were more successful than the ones in Estonia and females were less successful than the ones in Estonia (Jürimäe \& Volbekiene, 1998).

Plate Tapping Test (PLT): In the plate tapping test, the average of the required time to touch to a total of 50 plates were found as $12.80 \pm 2.36$ for females and as $14.44 \pm 2.00$ for males $(p<0.00)$. For 12 years of age, female average was $11.34 \pm 1.96$ and male average was $11.57 \pm 2.57(\mathrm{p}>.059)$. For 13 years of age, female average was $11.07 \pm 2.92$ and male average was $11.25 \pm 2.31(\mathrm{p}>0.72)$. For 14 years of age, female average was $10.05 \pm 2.02$ and male average was $10.27 \pm 2.48(\mathrm{p}>0.65)$. For 15 years of age, female average was $10.54 \pm 1.79$ and male average was $10.02 \pm 2.06(\mathrm{p}>0.15)$. For 16 years of age, female average was $10.45 \pm 1.96$ and male average was $10.01 \pm 1.62(\mathrm{p}>0.16)$. Lastly, for 17 years of age, female average was $10.13 \pm 1.33$ and male average was $09.87 \pm 1.47(\mathrm{p}<0.00)$.

It is seen that in the 11-year-old age groups, females are faster than males in test. In the 17 years of age groups, males were faster than females in the test. It was seen that there was no statistical difference between the 
genders in the 12-16 age groups, but considering average values, the coordination and speed shown in the test were higher for males than for females as the age increased.

The studies in the literature are similar to these data. When comparing the countries in the plate tapping test of 12-17 age group, it was determined that male and female students in Kosovo had a faster and better coordination than the students in Spain, Latvia, and Estonia (Casajús, Leiva, Villarroya, Legaz, \& Moreno, 2007; Jürimäe \& Volbekiene, 1998). 11-year-old female students in Kosovo were more successful than students in Latvia and Estonia. Also, 11-year-old male students in Kosovo were less successful than the students in Latvia but more successful than the ones in Estonia (Jürimäe \& Volbekiene, 1998).

Sit and Reach Test (SAR): According to sit and reach test, the value of 11-year-old females was found as $0.82 \pm 4.3$ and the male value was $0.1 \pm 4.1$ ( $\mathrm{p}>0.28$ ). For 12 -year-old individuals, female value was $0.9 \pm 5.8$ and male value was $0.6 \pm 4.9$ ( $>0.75)$. For 13 -year-old individuals, female value was $0.3 \pm 6.2$ and male value was $-2.1 \pm 5.1 \quad(\mathrm{p}<0.03)$. For 14-year-old individuals, female value was $2.2 \pm 7.7$ and male value was $-2.2 \pm 8.2(\mathrm{p}<0.01)$. For 15 years of age, female value was $2.0 \pm 8.1$ and male value was $0.6 \pm 8.6$ $(\mathrm{p}>0.36)$. For 16 years of age, female value was $1.0 \pm 9.6$ and male value was $1.0 \pm 8.3$ ( $p>0.99$ ). Lastly, for 17 years of age, female value was $2.3 \pm 7.3$ and male value was $2.3 \pm 8.0(\mathrm{p}>0.40)$. It was observed that in the sit and reach test, females were more flexible than males in 13-14 age groups. In the 11, $12,15,16$, and 17 age groups, there was no statistically significant difference between males and females.

According to these results, the values of the test in this study were lower than those in Latvia and Estonia. However, since the measurement method of sit and reach test was not mentioned in the study done by Jürimäe and Volbekiene (1998), it was thought that the difference between the values was caused by the usage of a different method (Jürimäe \& Volbekiene, 1998). According to the norm values of sit and reach test which were given by Australian College Sport and Fitness (2013), it was seen that the sit and reach test values in this study were normal (Flexibility Test 2013). Similarly, the results of a study on basketball players by Fresno et al. (2012) in England showed that the values of sit and reach test were normal (Fresno, Sánchez, \& Ravé, 2012).

Standing Broad Test (SBJ): According standing broad test, the average of 11-year-old females was found as $1.29 \pm .24$ and male average was found as $1.29 \pm 0.21$ ( $>00.97)$. For 12 years of age, female average was $1.38 \pm 0.19$ and male average was $1.54 \pm 0.24(p<0.00)$. For 13 years of age, female average was $1.37 \pm 0.26$ and male average was $1.62 \pm 0.29(\mathrm{p}<0.009)$. For 14 years of age, female average was $1.54 \pm 0.23$ and male average was 
$1.81 \pm 0.24(\mathrm{p}<0.00)$. For 15 years of age, female average was $1.57 \pm 0.18$ and male average was $1.85 \pm 0.29(\mathrm{p}<0.00)$. For 16 years of age, female average was $1,53 \pm 0.26$ and male average was $1.91 \pm 0.31(\mathrm{p}<0.00)$. Lastly, for 17 years of age, female average was $1.60 \pm 0.29$ and male average was $1.98 \pm 0.50$ $(\mathrm{p}<0.00)$. There was no statistically significant difference between males and females in 11-year-old age group in this test. In the 12-17 age group, males were statistically better than females in the explosive force.

The results of this study are similar to those in the literature. Comparing the countries, it was observed that the values of the students in Kosovo were lower than the values of the students in Latvia and Estonia (Jürimäe \& Volbekiene, 1998). According to the values of students in Colombia and India, the values of 12-17-year-old males and females in Kosovo were higher. In the 11-age group, the values of females in Kosovo were higher than those of females in Colombia and India but values of males were lower (Alexander et al., 2016). Compared to the values of the students in Macedonia, the females in Kosovo were more successful than them (Gontarev, Zivkovic, Velickovska, \& Naumovski, 2014). Compared to the values of 12-16-year-old males and 15-16-year-old females in Africa, males in Kosovo were more successful. Comparing to 11-year-old males and 1214-year-old females, 11-year-old males were less successful than 12-14-yearold females in Kosovo. In terms of standing broad test values, 11-year-old students of Kosovo and Africa had similarities (Nhantumbo et al., 2012)..

Handgrip Strength Test (HGR): In the study, according to hand grip strength test, average of right hand grip force was found as $17.2 \pm 5.2$ for 11year-old females and as $23.6 \pm 4.5$ for 11 -year-old males $(\mathrm{p}<0.00)$. For 12 years of age, female average was $20.4 \pm 6.1$ and male average was $23.8 \pm 6.2$ $(\mathrm{p}<0.00)$. For 13 years of age, female average was $24.9 \pm 5.1$ and male average was $29.6 \pm 6.7(p<0.00)$. For 14 years of age, female average was $27.9 \pm 6.2$ and male average was $36.8 \pm 9.5(\mathrm{p}<0.00)$. For 15 years of age, female average was $29.5 \pm 6.1$ and male average was $42.6 \pm 8.5(\mathrm{p}<0.00)$. For 16 years of age, female average was $30.4 \pm 5.8$ and male average was $46.8 \pm 9.3$ $(\mathrm{p}<0.00)$. For 17 years of age, female average was $31.0 \pm 5.8$ and male average was $49.9 \pm 9.9(\mathrm{p}<0.00)$.

Average of left hand grip strength was found as $16.4 \pm 5.2$ for 11-yearold females and as $23.1 \pm 4.4$ for males $(\mathrm{p}<0.00)$. For 12 years of age, female average was $19.1 \pm 6.2$ and male average was $23.1 \pm 6.2(p<0.00)$. For 13 years of age, female average was $24.2 \pm 5.8$ and male average was $28.5 \pm 6.7$ $(\mathrm{p}<0.00)$. For 14 years of age, female average was $27.5 \pm 6.4$ and male average was $34.3 \pm 9.0(p<0.00)$. For 15 years of age, female average was $28.0 \pm 6.8$ and male average was $39.8 \pm 8.0(\mathrm{p}<0.00)$. For 16 years of age, female average was $29.2 \pm 5.2$ and male average was $44.5 \pm 9.2(\mathrm{p}<0.00)$. For 17 years of age, female average was $29.8 \pm 5.6$ and male average was 
$47.9 \pm 10.1(\mathrm{p}<0.00)$. According to the results obtained in this study, it was observed that hand grip strength was statistically higher in males than females.

As can be seen, in both genders, the results showed that hand grip strength was higher in the right hand than in the left hand. According to Przybyla, Coelho, Akpinar and Sainburg (2013), the right hand is known as the dominant hand (Przybyla, Coelho, Akpinar, \& Sainburg, 2013). The results of other studies on hand grip strength show similarities with the results of this study.

Considering hand grip strength according to countries, students from Kosovo had higher values than students from Africa, Colombia, and India (Alexander et al., 2016; Nhantumbo et al., 2012). The same results were achieved between Kosovo and Latvia except for 11-year-old females and 16year-old males. It was seen that 11-13-year-old females in" Kosovo were more unsuccessful than females in Estonia but 14-17-year-old females were more successful. Males in 11, 13, 15, 16, 17 age group in Kosovo are less successful than those in Estonia while males in 12 and 14 age group were more successful (Jürimäe \& Volbekiene, 1998).

Max Sit-Ups (30 sec) (SUP): According to Max Sit-Up test in 30 seconds, the average of completed and correct sit-ups within 30 seconds was found as 15.8 \pm 3.4 for 11-year-old females and as $17.5 \pm 4.8$ for 11-year-old males $(\mathrm{p}<0.04)$. For 12 years of age, female average was $17.1 \pm 4.6$ and male average was $22.8 \pm 4.86 .2(\mathrm{p}<0.00)$. For 13 years of age, female average was $18.4 \pm 4.0$ and male average was $22.5 \pm 3.7(\mathrm{p}<0.00)$. For 14 years of age, female average was $18.8 \pm 4.6$ and male average was $24.1 \pm 3.0(\mathrm{p}<0.00)$. For 15 years of age, female average was $20.9 \pm 4.2$ and male average was $25.4 \pm 4.6$ $(\mathrm{p}<0.00)$. For 16 years of age, female average was $20.8 \pm 4.9$ and male average was $26.4 \pm 4.8(\mathrm{p}<0.00)$. For 17 years of age, female average was $27.5 \pm 5.3$ and male average was $31.2 \pm 3.6(\mathrm{p}<0.00)$. The maximal number of sit-ups within 30 seconds was statistically higher in males than in females.

Considering other countries, the values of students in Kosovo were lower than those of Latvia (11-16-year old individuals), Estonia (11-16-year old individuals) and Poland in terms of the max sit-ups test in 30 seconds (Jürimäe \& Volbekiene, 1998; Wilczewski et al., 1996). In 17 years of age group, males and females in Kosovo were more successful than the students in Latvia and Estonia (Jürimäe \& Volbekiene, 1998).

Bent Arm Hang Test (BAH): In Bent Arm Hang test, the time of hanging to bar was found as $3.84 \pm 1.02$ for 11-year-old females and as $7.30 \pm 4.51$ for 11 -year-old males $(\mathrm{p}<0.00)$. For 12 years of age, female value was $4.89 \pm 3.26$ and male value was $8.61 \pm 6.75(p<0.00)$. For 13 years of age, female value was $4.62 \pm 2.52$ and male value was $9.21 \pm 6.08(p<0.00)$. For 14 years of age, female value was $5.35 \pm 4.66$ and male value was $14.22 \pm 8.77$ 
$(\mathrm{p}<0.00)$. For 15 years of age, female value was $5.55 \pm 2.16$ and male value was $15.35 \pm 9.96(p<0.00)$. For 16 years of age, female value was $7.91 \pm 1.94$ and male value was $20.92 \pm 12.04(\mathrm{p}<0.00)$. For 17 years of age, female value was $7.86 \pm 6.26$ and male value was $21.32 \pm 8.32(p<0.00)$. According to the results obtained, it was determined that the static strength of the arms was statistically higher in males than females.

Compared to the countries, it was observed that the values of Bent Arm Hang test of females in 11-16 age group and males in 11-14 age group in Kosovo were lower than the values of African students. Also, it was observed that 15-16-year-old males in Kosovo had higher values than African students (Nhantumbo et al., 2012). In the city of Malishevë of Kosovo, flat arm hang test was performed in measuring the static strength of the arms by Berisha and Çilli (2016). The values were found as 92.75 for males in 15 and 16 years of age groups (Berisha \& Çilli, 2016). In the arm static strength test, the students in Kosovo were unsuccessful in comparison with the students in Spain, Latvia, and Estonia (Casajús et al., 2007; Jürimäe \& Volbekiene, 1998).

10x5 meter Shuttle Run Test (SHR): The time required to complete 10x5 meter Shuttle Run Test was found as $22.42 \pm 1.19$ for 11-year-old females and as $22.69 \pm 1.37$ for males $(p>0.30)$. For 12 years of age, female time was $22.75 \pm 1.43$ and male time was $21.37 \pm 1.79(\mathrm{p}<0.00)$. For 13 years of age, female time was $22.78 \pm 1.47$ and male time was $21.46 \pm 2.15(\mathrm{p}>0.24)$. For 14 years of age, female time was $21.24 \pm 3.26$ and male time was $20.58 \pm 1.72(p<0.00)$. For 15 years of age, female time was $23.89 \pm 2.82$ and male time was $20.84 \pm 2.30(\mathrm{p}<0.00)$. For 16 years of age, female time was $24.59 \pm 2.49$ and male time was $21.12 \pm 3.75(\mathrm{p}<0.00)$. For 17 years of age, female time was $24.06 \pm 3.85$ and male time was $21.38 \pm 3.78(\mathrm{p}<0.00)$.

There was no statistically significant difference between males and females in the 11-14 age groups in this agility test. Also, in 12, 13, 15, 16 and 17 age groups, it was statistically found that males were more successful than females in this test. Considering the averages of this test, it was thought that the similarity between males and females in agility and speed skills in 11 and 14 age groups was influenced by adolescence period. According to Coleman and Hendry (1999), the development rate of motor characteristics such as speed, agility, and strength varies during the adolescence period (Coleman \& Hendry, 1999).

In other scientific studies on this test, comparing the countries, it was seen that the students in Kosovo were less successful than 15-year-old males in Africa and students in Latvia in terms of the test. Also, 11-15-year-old males and 11-16-year-old females in Africa were more successful than students in Estonia (Jürimäe \& Volbekiene, 1998; Nhantumbo et al., 2012). Comparing the values of the students in Serbia, it was seen that females are 
faster and more agile than males (Sibinović, Mandarić, Mikalacki, \& Stojiljković, 2011).

20-meter Endurance Test (ESR): In 20-meter Endurance Test averages of the levels were found as $3 / 2 \pm 0.73$ for 11 -year-old females and as $4 / 3 \pm 1.2$ for males $(p<0.00)$. For 12 years of age, female average was $3 / 2 \pm 1.4$ and male average was $4 / 6 \pm 1.5(\mathrm{p}<0.00)$. For 13 years of age, female average was $3 / 5 \pm 1.0$ and male average was $4 / 7 \pm 1.5(p<0.00)$. For 14 years of age, female average was $3 / 3 \pm 0.75$ and male average was $4 / 9 \pm 1.8(\mathrm{p}<0.00)$. For 15 years of age, female average was $3 / 2 \pm 0.99$ and male average was $5 / 0 \pm 1.5$ $(p<0.00)$. For 16 years of age, female average was $3 / 3 \pm 1.0$ and male average was $5 / 1 \pm 1.2(p<0.00)$. For 17 years of age, female average was $3 / 8 \pm 1.4$ and male average was $5 / 7 \pm 1.3(p<0.00)$.

According to the obtained values, it was seen that males were more enduring than females in the endurance test. At the same time, the development of endurance was parallel to age in all age groups. For instance; the development of endurance of 11-13-year-old females showed increase parallel with age. According to the study of Coleman and Hendry (1999) in the literature, the development of endurance varies during adolescence period (Coleman \& Hendry, 1999). Because of this, the motor development of the children can be early or late in adolescence period (Coleman \& Hendry, 1999).

Considering the countries, the endurance values of the students in Kosovo were lower than the values of the students in Spain, Latvia, and Estonia (Casajús et al., 2007; Jürimäe \& Volbekiene, 1998). As a result of the study conducted by McVeigh et al. (1995), it was seen that $20 \mathrm{~m}$ shuttle run values were higher than the values of 13-year-old male students in Kosovo (McVeigh, Payne, \& Scott, 1995).

\section{Conclusion And Suggestion}

To sum up, it was observed that there were differences between the physical fitness characteristics of the 11-17-year-old male and female students living in Kosovo.

When the anthropometric values of 11-17-year-old students were examined, it was seen that there was no statistically difference between males and females in adolescence, but males were heavier and taller as the age increased. There was no statistically significant difference in the Body Mass Index between 11-16-year-old females and males but 17-year-old males had higher Body Mass Index values than the values of females.

It was observed that students in Kosovo were taller than the students in Sweden. According to height, weight and Body Mass Index, students in Kosovo were shorter, lighter and had lower Body Mass Index than the students living in Norway. 
According to the World Health Organization (WHO) height values and Body Mass Index values, children living in Kosovo are taller and have lower Body Mass Indices.

While there was no statistically significant difference between males and females aged 12-16 in balance ability, males were more successful than females in 11 and 17-year-old age groups.

While there was no statistically significant difference between 12-16year-old females and males in plate tapping test, females in 11-year-old age group were more successful than males. In the 17-year-old age group, males were more successful than females. As it is seen, in the test of speed of movement of arms, females are more successful at younger ages than males. However, as age increases, males become more successful than females.

There was no statistically significant difference between females and males of 11, 12, 15, 16, and 17-year-old age groups in sit and reach test, but females were more successful than males in 13-14-year-old age group.

While there was no statistically significant difference between the 11year-old females and males in the values of the standing broad jump test, 1217-year-old males were more successful than females.

It was observed that in $12,13,15,16,17$-year-old age group, males were more successful than females in the $20 \mathrm{~m}$ endurance test, but there was no statistically significant difference between 11 and 14 years old females and males.

It was observed that 11-17 years old males achieved more successful results than females in hand grip strength test, max sit-ups in 30 seconds, bent arm hang test, and $20 \mathrm{~m}$ endurance test.

When the values of the students in different countries and the measured values of students in Kosovo were compared;

Children in Latvia were more successful in height, balance test, max sit-ups (30s) test, bent arm hang test and 20-m shuttle run test compared to children in Kosovo, but they were unsuccessful in weight, plate tapping, hand grip strength and $10 \times 5 \mathrm{~m}$ shuttle run test. The values of height and weight tests of the students in Estonia were lower than the values of the students in Kosovo. However, it was seen that they were successful in sit and reach, standing broad jump, max sit-ups in 30 seconds, bent arm hang, 10x5m shuttle run and $20 \mathrm{~m}$ endurance test. In plate tapping test, it was seen that males in Kosovo were more successful than the females. Students in Colombia were seen to be more successful in the Body Mass Index, standing broad jump and hand grip strength tests than the students in Kosovo. Students in India were found to be less successful in the Body Mass Index, standing broad jump and hand grip strength tests than the students in Kosovo. Students in Poland were more successful in the balance test than the students in Kosovo and females were successful according to males. Children in Spain 
were more successful in bent arm hang test than the children in Kosovo. It was seen that females in Serbia were unsuccessful in comparison with the females in Kosovo in bent arm hang test, on the other hand, males were successful. Considering standing broad jump test, female students in Macedonia were more unsuccessful than the female students in Kosovo, but males are more successful. Children in Scotland were more successful in the $20 \mathrm{~m}$ endurance test than children in Kosovo. The values of the sit and reach test given by Australian College Sport and Fitness were similar to the values of the children in Kosovo. The values of basketball players in sit and reach test in England were similar to the values of the children in Kosovo. Students in Africa were unsuccessful in hand grip strength and 10x5 m shuttle run tests compared to students in Kosovo. The students in Africa were more successful in bent arm hang test than the students in Kosovo. In standing broad jump test, females in Africa were more successful than females in Kosovo, but males were unsuccessful.

As can be seen, students in Kosovo achieved more successful values in terms of anthropometric and motoric characteristics such as height, weight and Body Mass Index, plate tapping, hand grip strength and 10x5 m shuttle running in comparison with students in other countries. However, students in Kosovo were found to be unsuccessful in motor tests such as balance test, standing broad test, bent arm hang test and $20 \mathrm{~m}$ endurance test, in comparison with students inother countries.

As a conclusion, it is observed that students in Kosovo are more successful than the other countries with regard to motoric tests such as the anthropometric characteristics, which are thought to be more related to genetics, and speed/agility of arms and legs. On the other hand, they are unsuccessful in comparison with other countries with regard to flexibility and endurance in tests which are thought to be influenced by factors such as lifestyle, nutrition, and training.

This situation may due to the deficiency of the program and processing of physical education and sports course in Kosovo. Hergüner, Önal, Berisha and Yaman (2016) stated that the program content is not suitable for some age groups and there are insufficient actions for motor skills development and sports branches are not properly organized. These are negative points of physical education and sports program in Kosovo (Hergüner, Önal, Berisha, \& Yaman, 2016).

In the light of this information, the study suggested that it would be useful to reorganize physical education and sports lessons in Kosovo and increase the weekly lesson hours. Similar suggestions were presented by Hergüner, Önal, Berisha and Yaman (2016) in a study conducted on Physical Education and Sports course in Kosovo (Hergüner et al., 2016). In addition, 
the use of the EuroFit Test Battery is recommended for systematic monitoring of the development of children in physical education classes.

\section{Acknowledgment}

This work was supported by the EBDTEZ-2016-70-02-003 project file and the Sakarya University Scientific Research Projects Coordination Unit.

\section{References:}

1. Adhikari, A., \& McNeely, E. (2015). Anthropometric Characteristic, Somatotype and Bodym Composition of Canadian Female Rowers American Journal of Sports Science, 3(3), 61-66. doi: 10.11648/j.ajss.20150303.15

2. Agjencia e Statistikave të Kosovës. (2014). Kosova: Agjencia e Statistikave të Kosovës Retrieved from http://askdata.rksgov.net/PXWeb/pxweb/sq/askdata/.

3. Alexander, J., Sepúlveda, R., Vélez, R. R., Bautista, J. E. C., Izquierdo, M., \& Hermoso, A. G. (2016). Physical fitness and anthropometric normative values among Colombian-Indian schoolchildren. MBP Public Health, 16(962), 2-15. doi: 10.1186/s12889-016-3652-2

4. Asmussen, E., Klissouras, V., Tuxworth, B., Lofi, A., \& Leger, L. (1983). Sport testing physical eurofit In F. Karaesk (Ed.), TESTING PHYSICAL FITNESS EUROFIT Experimental Battery (pp. 1-83). Strasbourg Council of europe

5. Berisha, M., \& Çilli, M. (2016). 15-16 Yaş Çocuklarda Temel Cimnastik Derslerinde Kazanılan Farklı Kuvvet Türlerinin Cimnastik Performansı Üzerine Etkilerinin İncelenmesi. CBÜ Beden Eğitimi ve Spor Bilimleri Dergisi, 11(1), 37-45. Retrieved from http://edergi.cbu.edu.tr/ojs/index.php/besyo/article/view/832/331

6. BMI-for-age Boys 5 to 19 years (2007). World Health Organization Retrieved from http://www.who.int/growthref/bmifa_boys_5_19years_per.pdf?ua=1.

7. BMI-for-age Girls 5 to 19 years. (2007). World Health Organization Retrieved from http://www.who.int/growthref/bmifa_girls_5_19years_per.pdf?ua=1.

8. Casajús, J. A., Leiva, M. T., Villarroya, A., Legaz, A., \& Moreno, L. A. (2007). Physical Performance and School Physical Education in Overweight Spanish Children Annals of Nutrition and Metabolism, 51, 288-296. doi:10.1159/000105459 
9. Coleman, J., \& Hendry, L. B. (1999). The Nature of Adolosence The Nature of Adolosence (3 edition ed., pp. 277). London and New York: Routelge

10. Council of Europe. (1987). Of the committee of ministers to member states on the eurofit tests of physical fitness. (R (87) 9). Europe Council of Europe Committee of Ministers Retrieved from https://www.coe.int/t/dg4/epas/resources/texts/Rec(87)9_en.pdf.

11. Fjørtoft, I., Pedersen, A., Sigmundsson, H., \& Vereijken, B. (2011). Measuring physical fitness in children who are 5 to 12 years old with a test battery that is functional and easy to administer. American Physical Therapy Association, 91(7), 1087-1095. Retrieved from http://ptjournal.apta.org/content/ptjournal/91/7/1087.full.pdf

12. Flexibility Test (2013). Australia Australian College Sport and Fitness Retrieved from http://acsf.edu.au/pdf/Flexibility_Test_Sit_and_Reach.pdf.

13. Fresno, D. B., Sánchez, A. J. L., \& Ravé, J. M. G. (2012). Fitness Level and Body Composition of Elite Female Players in England Basketball League Division I. International Journal of Sport and Exercise Science, 4(2), 15-24. Retrieved from http://web.nchu.edu.tw/ biosimulation/journal/pdf/vol-4-no02/vol-4no-2-b-0001.pdf

14. Gontarev, S., Zivkovic, V., Velickovska, L. A., \& Naumovski, M. (2014). First normative reference of standing long jump indicates gender difference in lower muscular strength of Macedonian school children. Health, 6(1), 99-106. Retrieved from https://file.scirp.org/pdf/Health_2014012610191180.pdf

15. Height-for-age Boys 5 to 19 years (2007). Worl Health Organization (WHO) Retrieved from http://www.who.int/growthref/hfa_boys_5_19years_per.pdf?ua=1.

16. Height-for-age Girls 5 to 19 years. (2007). Worl Health Organization (WHO) from http://www.who.int/growthref/hfa_girls_5_19years_per.pdf?ua=1.

17. Hergüner, G., Önal, A., Berisha, M., \& Yaman, M. S. (2016). The Comparison of Physical Education and Sports Lessons Applied in Education Systems of Turkey and Kosovo. Universal Journal of Educational Research, 4(9), 1985-1993. doi:10.13189/ujer.2016.040908

18. Jürimäe, T., \& Volbekiene, V. (1998). Eurofit Test Results in Estonian and Lithuanian 11 to 17-Year-Old Children: A Comparative Study. European Journal of Physical Education, 3(2), 178-184. Retrieved from http://www.tandfonline.com/doi/abs/10.1080/1740898980030206 
19. Kemper, H., \& Mechelen, W. (1996). Physical Fitness Testing of Children: A European Perspective. Pediatric Exercise Science: Human Kinetics Pubiishers, Inc, 8, 201-2014. Retrieved from http://eds.a.ebscohost.com/eds/pdfviewer/pdfviewer?vid=1\&sid=ef96 0ef0-c7d3-440c-92ef-ea7d6ef55321\%40sessionmgr4010\&hid=4102

20. McVeigh, S. K., Payne, A. C., \& Scott, S. (1995). The Reliability and Vaiidity of the 20-Meter Shuttle Test as a Predictor of Peak Oxygen Uptake in Edinburgh School Children, Age 13 to 14 Years. Human Kinetics Publishers, Inc., 7, 69-79. Retrieved from http://eds.b.ebscohost.com/eds/pdfviewer/pdfviewer?vid=1\&sid=5f9a f195-fa19-44e1-8412-c03d5266d35c\%40sessionmgr104

21. Nhantumbo, L., Saranga, S., Prista, A., Basso, L., \& Maia, J. (2012). Allometric study of functional fitness of children and adolescents in a rural area of Mozambique. Brazilian Journal of Kinanthropometry, 14(5), 508-516. doi:http://dx.doi.org/10.5007/19800037.2012v14n5p507

22. Normal Adolescent Development. (2003). USA: American Academy of Child \& Adolescent Psychiatry Retrieved from https://www.communities.qld.gov.au/resources/childsafety/practicemanual/physical-cognative-milestones.pdf.

23. Örjan, E., Kristjan, O., \& E, B. (2005). Physical performance and body mass index in Swedish children and adolescents. Scandinavian Journal of Nutrition, 49(4), 172-179. doi:10.1080/11026480500441275

24. Przybyla, A., Coelho, C. J., Akpinar, S., \& Sainburg, R. L. (2013). Sensorimotor performance asymmetries predict hand selection. Neuroscience, 228, 349-360. Retrieved from http://www.sciencedirect.com/science/article/pii/S030645221201066 4\#

25. Sibinović, A., Mandarić, S., Mikalacki, M., \& Stojiljković, S. (2011). Effects Of High And Low Aerobics Programme On Motor Abilities Of The Eighth Grade Elementary School Students. Physical Education / Tjelesna i zdravstvena kultura, 446-453.

26. Singh, D., Rahman, N., Rajikan, R., Zainudin, A., Nordin, N., Karim, Z., \& Yee, Y. (2015). Balance and Motor Skills among Preschool Children Aged 3 to 4 Years Old. Malaysian Journal of Medicine and Health Sciences, 11(1), 63-68. Retrieved from http://www.medic.upm.edu.my/upload/dokumen/FKUSK1_Article_7. pdf

27. Volbekiene, V., \& Griciltte, A. (2007). Health-related physical fitness among schoolchildren in Lithuania: A comparison from 1992 to 2002. Scandinavian Journal of Public Health, 35, 235-242. Retrieved from 
http://eds.a.ebscohost.com/eds/pdfviewer/pdfviewer?vid=1\&sid=e601 1ab0-e4ad-4f85-9334-1d4b7c8bb763\%40sessionmgr4010\&hid=4210 28. Wilczewski, A., Sklad, M., Krawczyk, B., Saczuk, J., \& Majle, B. (1996). Physical Development and Fitness of Children from Urban and Rural Areas as Determined by EuroFit Test Battery. Biology of Sports, 13(2), 113-126. Retrieved from https://books.google.com.tr/books?hl=en\&lr=\&id=pVwpTcHIJYsC\& oi $=$ fnd \&pg $=$ PA113\&dq=flamingo+balance+test+eurofit\&ots $=$ COege Ae4CC\&sig=lsfLRJO1_wmU7Xbt2QfFoV2ne1o\&redir_esc=y\#v=on epage \&q\&f=false 